\title{
Business Administration Students' Evaluation of Their Learning Environment
}

\author{
MA Germina Esquivel-Santos
}

College of Management and Business Technology, Nueva Ecija University of Science and Technology, Philippines

\begin{abstract}
The academic environment is one of the numerous factors affecting academic performance and achievement. This paper assessed the academic environment of a university in terms of safety, cleanliness and comfortability. The descriptive method was used. This paper surveyed a total of 217 respondents, including 84 male and 217 female business administration students from Nueva Ecija University of Science and Technology. This study examined how college students evaluated their learning environment in terms of safety, cleanliness, and comfortability. Safety of their learning environment topped on the students' evaluation as compared to cleanliness and comfortability. They feel safe inside the school building and secured that their learning environment is free from harm that drugs may cause. Students' participation was very important in maintaining their learning environment. Healthy and clean food was also prepared for them by their school. Strong evaluation result in the students' learning environment was the positive and healthy interactions between instructors, staff, and student as it leads to the academic success of the students. However, some problems encountered are in terms of monitoring of guards to school vicinity is not regularly conducted, cleanliness of the comfort rooms was not observed, and fire exit was not easily accessible.
\end{abstract}

Keywords-Academic Environment, Institutional Factor, Cleanliness, Safety.

\section{INTRODUCTION}

The academic environment is one of the numerous factors affecting academic performance and achievement. There are several different and hidden aspects affecting how students perceive and experience their education, ranging from class size, leisure time, and assessment systems to relationships with classmates and teachers, the ethical environment, and extracurricular possibilities (Divaris et al., 2008). Academic environment should be built with a focus on deep learning, student-centered instruction, and outcome-driven course design (Philips, 2007).
In higher education, academic environment considerations include whether the institution is private or public, as well as the size and structure of the institution (in two-type systems) (Baskaya \& Klumpp, 2014). The physical environment and facility conditions at higher educational institutions contribute to student comfort and comprehension of courses offered, hence impacting students' learning and final accomplishment (Abbasi \& Mir, 2012).

Evidently, positive attitudes about the classroom environment have a direct effect on academic accomplishment but also, and perhaps more crucially, on qualitative learning outcomes (Lizzio et al., 2002). Academic environment factors affecting students' performance include inadequate funding, a lack of frequent curricular review, overpopulation, student unrest, faculty strikes, inadequate infrastructure, strained relations between the university and the government, and insufficient teaching and research facilities (Christiana, 2011). In addition, academic environments have an impact on social cognitions and the formation of identities (Adams et al., 2000).

On the contrary, academic environment factors, regardless of their importance, cannot influence students' performance in isolation from other factors (Osaikhiuwu,2014). The research found a lack of research on institutional factors. This is why it is critical to understand the academic environment in the Philippines.

\section{OBJECTIVES OF THE STUDY}

This paper assessed the academic environment of a university in terms of safety, cleanliness and comfortability.

\section{METHODOLOGY}

The descriptive method was used to gather data on the presentation of current situations, to characterize the essence of the situation as it was at the time of the research, and to examine the causes of specific events (Camic et al., 2003). This paper surveyed a total of 217 respondents, including 84 
male and 217 female business administration students from Nueva Ecija University of Science and Technology. The researcher used likert-scale questionnaires to ascertain

\section{RESULTS AND DISCUSSIONS}

Table 1. Safety of the Learning Environment

\begin{tabular}{|c|c|c|}
\hline Items & Mean & Verbal Interpretation \\
\hline 1. The electricity is installed properly. & 2.55 & Agree \\
\hline 2. The guards do their rounds regularly. & 2.41 & Disagree \\
\hline 3. In case of emergency, the fire exit is available and easy to find. & 2.45 & Disagree \\
\hline 4. The fire extinguisher is standing by. & 2.70 & Agree \\
\hline 5. The first aid kit is available. & 2.75 & Agree \\
\hline 6. The infirmary is always on guard. & 2.65 & Agree \\
\hline 7. The school is implementing earthquake and fire drills annually. & 2.58 & Agree \\
\hline 8. The school is a drug free zone. & 3.62 & Strongly Agree \\
\hline 9. It is tolerable to stay in the school when it rains even after class dismissal. & 2.60 & Agree \\
\hline 10. The students are safe inside the school building. & 3.91 & Strongly Agree \\
\hline Average weighted mean & 2.82 & Agree \\
\hline
\end{tabular}

Table 1 shows the evaluation of the students towards their learning environment in terms of safety. The student evaluated the safety of their learning environment with an average weighted mean of 2.82 , which has a verbal interpretation of "Agree". Students strongly agreed on Statement 10 "The students are safe inside the school building" (Mean = 3.91) and Statement 8 "The school is a drug free zone." (Mean = 3.62). On the other hand, students respondents' perceptions and to evaluate mean and weighted mean data (Vagias, 2006).

\begin{tabular}{|l|c|c|}
\hline \multicolumn{1}{|c|}{ Items } & Mean & Verbal Interpretation \\
\hline 1. The students wear proper uniforms. & 2.60 & Agree \\
\hline 2. There are proper bins and trash cans designated in every classroom. & 2.55 & Agree \\
\hline 3. The utility maintain the cleanliness of the department. & 2.69 & Agree \\
\hline 4. The students also participate and maintain the cleanliness of the department. & 3.66 & Strongly Agree \\
\hline 5. The campus is free from dirt and pollution. & 2.57 & Agree \\
\hline 6. The school canteen prepares food neatly. & 3.69 & Strongly Agree \\
\hline 7. The food prepared in school canteen is clean. & 2.54 & Agree \\
\hline 8. The school comfort rooms are always clean. & 2.41 & Disagree \\
\hline 9. The school observes proper waste disposal. & 2.52 & Agree \\
\hline 10. The school is free from vandalism & $\mathbf{2 . 7 8}$ & Agree \\
\hline \multicolumn{1}{|c|}{ Average weighted mean } & Agree \\
\hline
\end{tabular}

disagreed on Statement 3 "In case of emergency, the fire exit is available and easy to find." (Mean = 2.45) and Statement 2 "In case of emergency, the fire exit is available and easy to find." (Mean = 2.41). The data suggests that students may feel the safety inside the school and free from drugs. However, the may feel unsecure outside the building because guards are not always visible. Locating fire exits in the building easily was also a problem encountered by the students.

\section{Table 2. Cleanliness of the Learning Environment}


Table 2 shows the evaluation of students on the cleanliness of their learning environment in terms of cleanliness. Students evaluated the cleanliness of their learning environment with an average weighted mean of 2.78 that has a verbal interpretation of "Agree". They strongly agreed on Statement 6 "The school canteen prepares food neatly." (Mean = 3.69) and Statement 4 "The students also participate and maintain the cleanliness of the department." (Mean = 3.66.) However, students disagreed on Statement 8 "The school comfort rooms are always clean." (Mean $=2.4$. Participation of students is a good indicator to maintain a clean learning environment. Though food preparation was healthy and clean, it was found out that comfort room was not observed to be cleaned. Most people can learn and function productively in a disorganized atmosphere, whereas others prefer a clear, orderly environment. Students are no different. In an orderly environment, students may think more organized, which leads to increased learning.

Table 3. Comfortability of the Learning Environment

\begin{tabular}{|l|c|c|}
\hline \multicolumn{1}{|c|}{ Items } & Mean & $\begin{array}{c}\text { Verbal } \\
\text { Interpretation }\end{array}$ \\
\hline 1. The classrooms are well ventilated and lighted. & 2.62 & Agree \\
\hline 2. The classroom is conducive learning. & 2.70 & Agree \\
\hline 3. The chairs and tables of the classroom are properly arranged and comfortable to use. & 2.60 & Agree \\
\hline 4. The comfort rooms are always clean and ready to use. & 2.61 & Agree \\
\hline 5. The school staff is courteous. & 3.82 & Agree \\
\hline 6. It is easy to reach the school premises by walking. & 2.67 & Agree \\
\hline 7. The students in school feel comfortable to report any harassment and bullying. & 3.76 & Agree \\
\hline 8. The school is free danger zone. & 2.50 & Agree \\
\hline 9. The school trees help students to relax. & 2.79 & Agree \\
\hline 10. The students always find what they want to read in library. & 2.72 & Agree \\
\hline \multicolumn{1}{|c|}{ Average weighted mean } & $\mathbf{2 . 6 8}$ & Agree \\
\hline
\end{tabular}

Table 3 shows the evaluation of students on the cleanliness of their learning environment in terms of cleanliness. Students evaluated the comfortability of their learning environment with an average weighted mean of 2.68 that has a verbal interpretation of "Agree". Students strongly agreed on Statement 5 "The school staff is courteous.", (Mean = 3.82) and Statement 7 "The students in school feel comfortable to report any harassment and bullying." (Mean $=76)$. The results indicate that healthy relationship among school stakeholders such as teachers, staff, and students is established. Positive and healthy interactions between instructors and students may be greatly useful at all levels of an educational establishment, including within the classroom and throughout the school environment as a whole.

\section{CONCLUSIONS AND RECOMMENDATIONS}

This study examined how college students evaluated their learning environment in terms of safety, cleanliness, and comfortability. Safety of their learning environment topped on the students' evaluation as compared to cleanliness and comfortability. They feel safe inside the school building and secured that their learning environment is free from harm that drugs may cause. Students' participation was very important in maintaining their learning environment. Healthy and clean food was also prepared for them by their school. Strong evaluation result in the students' learning environment was the positive and healthy interactions between instructors, staff, and student as it leads to the academic success of the students. However, some problems encountered are in terms of monitoring of guards to school vicinity is not regularly conducted, cleanliness of the comfort rooms was not observed, and fire exit was not easily accessible. 
The researcher recommends (1) to maintain the strengths found in the safety, cleanliness, and comfortability of the students' learning environment; (2) to conduct school analysis on the problems encountered make a development program to address these; (3) to give needs assessment must to the students to identify other opportunities for improvement; and (4) to conduct further research on how students' learning environment affect their academic success.

\section{REFERENCES}

[1] Abbasi, A. S., \& Mir, G. M. (2012). Impact of Teacher's Ability, Student's Work Ethics and Institutional Environment on Student Performance of University of Gujrat. Middle-East Journal of Scientific Research, 12(4), 572-579.

[2] Adams, G. R., Ryan, B. A., \& Keating, L. (2000). Family relationships, academic environments, and psychosocial development during the university experience: A longitudinal investigation. Journal of Adolescent Research, 15(1), 99-122.

[3] Başkaya, S., \& Klumpp, M. (2014). International data envelopment analysis in higher education: how do institutional factors influence university efficiency. Journal of Business and Economics, 5(11), 2085-2090.

[4] Camic, P. M., Rhodes, J. E., \& Yardley, L. E. (2003). Qualitative research in psychology: Expanding perspectives in methodology and design. American Psychological Association.

[5] Christiana, O. O. (2011). Modes of funding Nigerian universities and the implications on performance. Journal of International Education Research (JIER), 7(4), 75-82.

[6] Divaris, K., Barlow, P. J., Chendea, S. A., Cheong, W. S., Dounis, A., Dragan, I. F., ... \& Vrazic, D. (2008). The academic environment: the students' perspective. European Journal of Dental Education, 12, 120-130.

[7] Lizzio, A., Wilson, K., \& Simons, R. (2002). University students' perceptions of the learning environment and academic outcomes: implications for theory and practice. Studies in Higher education, 27(1), 27-52.

[8] Osaikhiuwu, O. C. (2014). Institutional factors affecting the academic performance of public administration students in a Nigerian University. Public Administration Research, 3(2), 171-177.
[9] Phillips, R. (2007). Pedagogical, institutional and human factors influencing the widespread adoption of educational technology in higher education.

[10] Vagias, W. M. (2006). Likert-type scale response anchors. clemson international institute for tourism. \& Research Development, Department of Parks, Recreation and Tourism Management, Clemson University. 